\title{
Adaptability of groundnut (Arachis hypogaea L.) genotypes over diverse environments evident by stability analysis of pod yield and seed oil content
}

\author{
M.Y. Ladole*, S.N. Deshmukh, P.V. Mahatale, P.N. Mane, E.R. Vaidya and A.R. Bhuyar
}

\begin{abstract}
Groundnut (Arachis hypogaea L.) is an important oilseed crop commercially cultivated in India. The adaptability and stability of some groundnut genotypes was assessed during 20112012 in different growing seasons (kharif, rabi and summer) with different sowing dates with combination of fertilizer levels at Oilseeds Research Unit at the Dr. Panjabrao Deshmukh Krishi Vidyapeeth, Akola, India. The pod yield and seed oil content were recorded. Pooled analysis of variance of pod yield and seed oil content over diverse environments revealed the presence of genotype $x$ environment interaction and significant differences among the genotypes and environments $(p<0.05)$. The partitioning of $G \times E$ interaction indicated that the linear component was significant $(p<0.05)$ against pooled deviation for both traits. The non-linear component (pooled deviation) was also significant ( $p<0.050$ when tested against the pooled error revealing presence of non-linear responses of the genotypes to the changing environments. The genotype AK 320 exhibited specific adaptability for favorable environments and the genotype AK 342 showed adaptability for unfavorable environments with respect to pod yield. However, both varieties were not stable across environments for the seed oil content though their seed oil content improved proportionate to the improving environment. The genotype AK 327 showed the highest general adaptability over diverse environments in respect of both pod yield and seed oil content. In general, the genotypes that showed high level of stability were not high yielders and the high yielders were found to be unstable in pod yield and seed oil content.
\end{abstract}

Keywords: Groundnut, pod yield, seed oil content, stability

\section{Introduction}

Groundnut (Arachis hypogaea L.) is one of the most important oilseed crops grown in India. Cultivated groundnut is a segmental amphidiploid $(2 n=4 x=40)$ with a basic chromosome number $x=10$. In India, groundnut is mainly grown in 11 different states covering an extent of 5.26 million ha. The crop has yielded of 6.96 million t of pods per annum with a productivity of $1323 \mathrm{~kg} / \mathrm{ha}$ (Anonymous, 2013). The most remarkable feature of this legume is its wide adaptability. Within a short period, the crop has spread to several parts of the world. In groundnut, a majority of target traits of economic importance are polygenic and are highly influenced by environment that hinders the achievable genetic gains in breeding programs. Genetic analysis of yield revealed a high influence of environment on pod yield 
(Zhang et al., 2011). High yielding cultivars with the least $G \times E$ interactions are normally desirable.

Yield and its contributing parameters are the most widely targeted traits of groundnut improvement program in the global scale. Selection for yield per se has been the major basis for improving groundnut productivity in the world (Nigam et al., 1991) but gains from such selection have been low and slow due to large $G \times E$ interaction observed for these traits. Stability analysis is an important tool to the breeder to understand the adaptability of crop variety and predict responses to various genotypes over a wide range of changing micro and macro environments. Thus, a study assessed the stability of adaptable genotypes of groundnut over locations or seasons. Use of stable genotypes in hybridization programs would lead to development of phenotypically stable high potential cultivars.

\section{Materials and Methods}

The present investigation on stability of performance of groundnut genotypes was conducted during pre-monsoon 2011, kharif 2011, rabi 2011 and summer 2012 at Oilseeds Research Unit, Dr. Panjabrao Deshmukh Krishi Vidyapeeth, Akola, India. Fourteen different environments were created by seven sowing dates and simulation of two fertilizer doses (RDF and $50 \%$ of RDF+ PSB and Rhizobium seed treatment) (Allard and Bradshaw, 1964) and these environments were designated as E1 to E14. Ten released varieties (seven belongs to Spanish bunch and three belongs to Virginia bunch group) and 16 breeding lines of advance generation were used. The trials in rabi and summer season were irrigated. Pod yield and seed oil content were recorded. Stability analysis was carried out by the method of Eberhert and Russell (1966).

\section{Results and Discussion}

Pooled analysis of variance for genotype by environment interaction revealed the presence of significant differences among the genotypes and environments for pod yield $(p<0.05$; Table 1$)$. The mean sum of squares due to $G \times E$ interaction was significant when tested against the pooled error. The mean sum of squares due to $C$ $\times E$ interaction in the linear component was also significant $(p<0.05)$ revealing that the behavior of the genotypes could be predicted over the environments precisely and accurately. The non-linear component arising due to the heterogeneity, measured as mean squares due to pooled deviation, was also significant $(p<0.050$ revealing the presence of non-linear responses of the genotypes to the changing environments. However, the magnitude of linear component, i.e. environment (linear) and $G \times E$ (linear) was higher than the non-linear component (pooled deviation), revealing that the prediction of stability could be reliable though it may get affected to some extent. 
Table 1. Analysis of variance for genotype $x$ environment interaction for pod yield and seed oil content

\begin{tabular}{|c|c|c|c|}
\hline \multirow{2}{*}{ Source } & \multirow{2}{*}{ d.f. } & \multicolumn{2}{|c|}{ Mean sum of square } \\
\hline & & Pod yield (g per plant) & Seed oil content (\%) \\
\hline Genotypes & 25 & $20.22^{* *}$ & $15.62 *$ \\
\hline Environments & 13 & $90.97 * *$ & $35.95^{*}$ \\
\hline Genotype x Environment & 325 & $4.03 * *$ & $0.54^{*}$ \\
\hline Total & 363 & 9.75 & 2.85 \\
\hline Pooled error & 700 & 0.60 & 0.08 \\
\hline $\begin{array}{l}\text { Environment + (Genotype } \\
\quad \text { xenvironment) }\end{array}$ & 338 & $7.38^{+}$ & $1.90^{+}$ \\
\hline Environment (Linear) & 1 & $1182.68^{+}$ & $467.35^{+}$ \\
\hline $\begin{array}{l}\text { Genotype ×Environment } \\
\quad \text { (Linear) }\end{array}$ & 25 & $9 \cdot 55^{+}$ & $0.82^{+}$ \\
\hline Pooled deviation & 312 & $3.44^{*}$ & $0.50 *$ \\
\hline
\end{tabular}

* Significant at $\mathrm{p}=0.05$ against poled error + Significant at $\mathrm{p}=0.05$ against pooled deviation

** Significant at $\mathrm{p}=001$ against poled error ++ Significant at $\mathrm{p}=0.01$ against pooled deviation

Pod yield is the most important character and is total of all components acting directly or indirectly in a community of many individual plants. Estimates of adaptability and stability parameters for pod yield and oil content in groundnut are presented in Table 1. The genotype AK 320 had a higher mean dry pod yield per plant with a regression coefficient greater than unity and a non-significant deviation from regression line, indicating specific adaptability of this genotype to favorable environmental conditions (Table 2). The genotype AK 342 had Bi-value less than unity with non-significant $S^{2}$ di, justifying its specific adaptability under poor environmental situations (Figure 1). Both AK 320 and 342 improved their seed oil content proportional to the improving environment but with low stability. The genotype AK 327 showed the highest general adaptability over diverse environments in respect of both pod yield and seed oil content. Similar results were also reported by Hariprasanna et al. (2008), Thaware (2009), Malik et al. (2009), Mothilal et al. (2010) and Kirmani et al. (2013). However, in a study conducted by Lal et al. (2006), no variety was found to be stable for pod yield and other characteristics studied.

\section{Oil content (\%)}

The pooled analysis of variance (Table 1) showed that there were significant differences amongst environments and genotypes $(p<0.05)$. Significant mean sum of squares $E+(G \times E)$ interaction revealed that the genotypes interacted with environmental conditions that existed in different growing seasons. The environment (linear) and $\mathrm{G} \times \mathrm{E}$ (linear) components were significant against pooled deviation $(p<0.05)$. The genotypes AK 159, AK 320 and CTMG 6 recorded higher oil content than the average with regression coefficient near to unity however, with a significant deviation from regression line indicating their suitability for favourable 
environments with unpredictable performance (Figure 2). The genotype AK 265 was found to be suitable for favourable situations with predictable performance as it posses high oil content with below average responsiveness (Regression coefficient bi $>1)$ and non-significant deviation from regression line ( $S^{2}$ di; $p>0.05$; Table 2). Results of similar nature were reported by Upadhaya et al. (2012) and Kirmani et al. (2013).

Table 2. Estimates of adaptability and stability parameters for pod yield and seed oil content in groundnut.

\begin{tabular}{|c|c|c|c|c|c|c|}
\hline \multirow{2}{*}{ Genotype } & \multicolumn{3}{|c|}{ Pod yield (g per plant) } & \multicolumn{3}{|c|}{ Seed oil content (\%) } \\
\hline & Mean & $\mathrm{Bi}$ & $\mathrm{S}^{2} \mathrm{di}$ & Mean & $\mathrm{Bi}$ & $\mathrm{S}^{2} \mathrm{di}$ \\
\hline TAG-24 & 9.50 & 0.56 & $4.30 * *$ & 49.50 & 0.82 & $0.27 * *$ \\
\hline AK-159 & 10.31 & 1.35 & $3.01 * *$ & 50.86 & 0.96 & $0.18 * *$ \\
\hline$J L-24$ & $9 \cdot 35$ & 1.13 & $1.73^{* *}$ & 49.21 & 0.86 & $0.23 * *$ \\
\hline JL-501 & 8.90 & 0.83 & $1.54 * *$ & 47.83 & 1.08 & $0.50 * *$ \\
\hline LGN-1 & 8.60 & 1.34 & $2.56 * *$ & 49.67 & 1.10 & $0.55^{* *}$ \\
\hline AK 12-24 & 8.75 & 0.97 & $1.89 * *$ & 49.42 & 1.10 & $0.13^{*}$ \\
\hline SB-XI & 8.85 & 1.04 & $2.19 * *$ & 49.40 & 0.82 & $0.21 * *$ \\
\hline AK-303 & 10.72 & 1.66 & $15.94 * *$ & 48.05 & 0.70 & $0.47^{* *}$ \\
\hline AK-265 & $9 \cdot 35$ & 1.35 & $2.26 * *$ & 50.32 & $1.28 *$ & 0.11 \\
\hline UF 70103 & 5.77 & $0.37 *$ & 0.26 & 48.61 & 1.45 & $1.04 * *$ \\
\hline AK-320 & 11.94 & $1.82 *$ & 0.54 & 49.67 & 1.05 & $0.21 * *$ \\
\hline AK-321 & 10.67 & $2.09 *$ & $2.14 * *$ & 50.09 & 1.17 & $0.63^{* *}$ \\
\hline AK-326 & 8.75 & 1.00 & $3.98 * *$ & 47.70 & 1.06 & $0.33^{* *}$ \\
\hline AK-327 & 10.47 & $0.64 *$ & 0.43 & 47.95 & 1.11 & 0.06 \\
\hline AK-330 & 9.83 & 0.99 & $2.00 * *$ & 47.52 & 1.16 & $0.29 * *$ \\
\hline AK-331 & 9.13 & 0.81 & $2.15^{* *}$ & 47.42 & 1.08 & $0.47^{* *}$ \\
\hline AK-335 & 9.99 & 0.86 & $4 \cdot 30 * *$ & 47.68 & 0.80 & $0.17 * *$ \\
\hline AK-336 & 10.26 & 1.27 & $1.42 * *$ & 47.70 & $0.62 *$ & $0.28 * *$ \\
\hline AK-337 & 10.40 & 1.23 & $2.39 * *$ & 47.84 & 0.97 & $0.26 * *$ \\
\hline AK-340 & 10.78 & 1.20 & $1.90 * *$ & 47.76 & $1.30 *$ & 0.11 \\
\hline AK-341 & 10.18 & 1.20 & $2.45^{* *}$ & 48.27 & 1.18 & $1.15^{* *}$ \\
\hline AK-342 & 9.88 & $0.45^{*}$ & 0.45 & 47.96 & 1.05 & $0.33 * *$ \\
\hline CTMG 6 & 9.20 & 0.58 & $4.83^{* *}$ & 50.29 & 1.09 & $0.67 * *$ \\
\hline ICGV-08135 & 8.46 & $0.49 *$ & $1.76 * *$ & 49.47 & $0.77^{*}$ & 0.07 \\
\hline NRC-6-5 & 7.59 & 0.61 & $1.60 * *$ & 49.94 & 0.87 & $0.53 * *$ \\
\hline RHRG-6083 & 9.21 & $0.17^{*}$ & $4.15 * *$ & 49.39 & $0.57 *$ & $0.47^{* *}$ \\
\hline General mean & 9.49 & & & 48.83 & & \\
\hline $\mathrm{SE}( \pm)$ & 0.51 & 0.27 & & 0.19 & 0.17 & \\
\hline$C D$ at $p=0.05$ & 1.01 & & & 0.38 & & \\
\hline
\end{tabular}

$\mathrm{Bi}=$ Regression coefficient; $\mathrm{S}^{2} \mathrm{di}=$ Deviation from regression line; $\mathrm{SE}=$ standard error; $\mathrm{CD}=\mathrm{critical}$ difference; * ** Significant at $\mathrm{p}=0.05$ and $\mathrm{p}=0.01$, respectively.

Different sets of genes may operate in different locations and in different seasons. In general, the genotypes that showed high level of stability were not high yielders and 
the high yielders were found to be sensitive to environment and unstable in respect of pod yield and seed oil content.

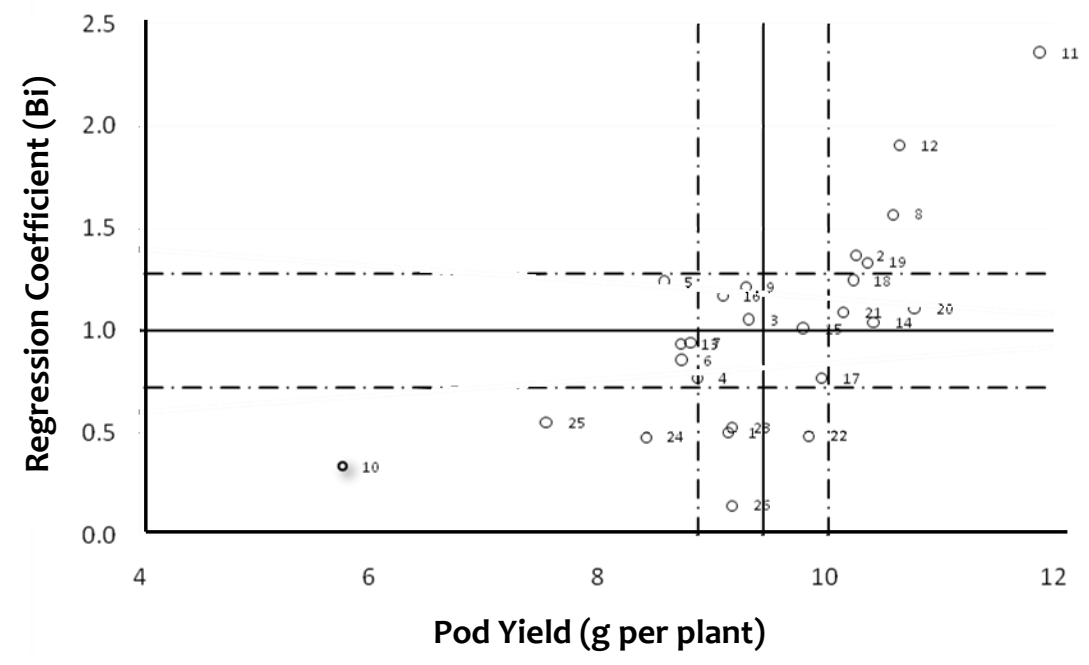

Figure 1. Stability parameters in respect of pod yield (mean performance). Solid symbols indicate significant deviation from the regression line $\left(\mathrm{S}^{2} \mathrm{di}\right)$.

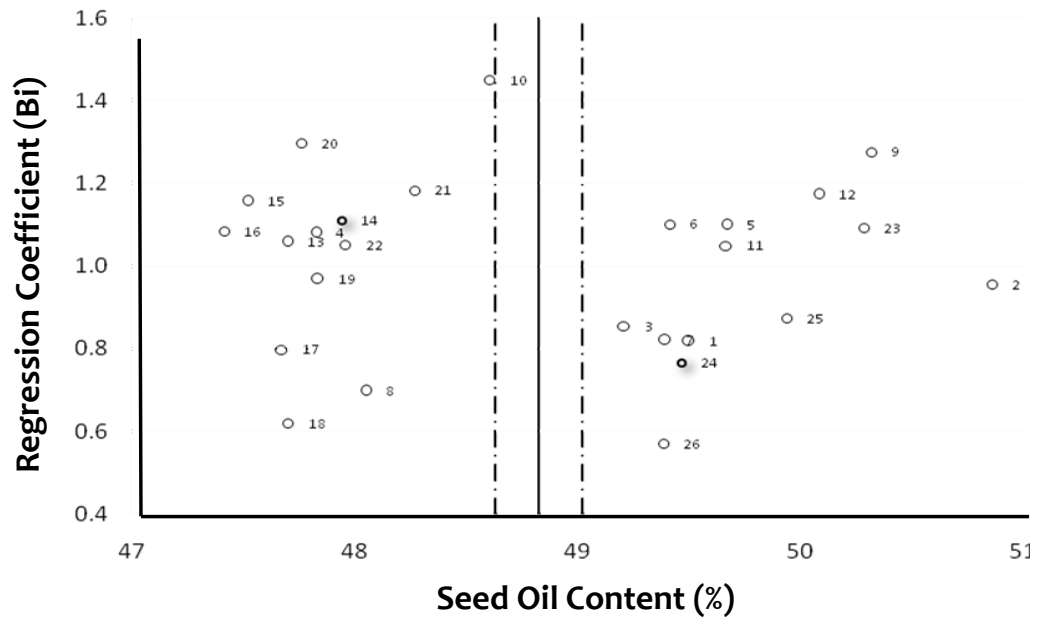

Figure 2. Stability parameters in respect of seed oil content (mean performance). Solid symbols indicate significant deviation from regression line $\left(\mathrm{S}^{2} \mathrm{di}\right)$.

\section{Conclusion}

None of the genotype tested were found to be having average stability pod yield. However, the genotype AK 320 exhibited below average stability and the genotypes AK 327 and AK 342 showed above average stability. For oil content, none of the genotype was found stable. However, the genotype AK 265 exhibited below average 
stability. There are better chances of utilizing these in hybridization programme to develop superior genotypes having stable performance than the existing ones.

\section{References}

Anonymous (2013): Annual Report (Kharif) 2012, AICRP-G, Directorate of Groundnut Research, Junagadh.

Allard, R.W. and Bradshaw, A.O. (1964): Implications of genotype environment interaction in applied plant breeding. Crop Sci. 4: 503-507.

Hariprasanna, K., Lal, C. and Radhakrishnan, T. (2008): Genotype x environment interaction and stability analysis in large seeded groundnut, Arachis hypogaea L. J. Oilseeds Res. 25(2): 126-131.

Kirmani, S., Venkataravana, M.P., Jagadeesha, B.N., Marappa, N. and Reddy, M.P. (2013): Stability analysis of groundnut genotypes for pod yield and its component traits over extended dates of sowing. Paper presented at "National Conference on Crop Improvement and Adaptive Strategies to Meet Challenges of Climate Change", held at UAS Bangalore, Feb 22-24, 2013, pp 149.

Lal, C., Radhakrishnan, T., Mathur, R.K., Minivel, P., Samdur, M.Y., Gor, H.K. and Chikani, B.M. (2006): Evaluation of groundnut varieties for yield and quality characters. Legume Res. 29(2): 102-105.

Malik S.N., Nawaz, N., Yousuf, M., Khan, M.A., Mirza, M.Y., Mohammad, A.S., Sher, M.A. and Masood, M.A. (2009): Stability performance for pod yield in groundnut. Pakistan J. Agric. Res. 22(3-4): 116-119.

Mothilal, P., Varman, V. and Manivannan, N. (2010): Stability analysis of foliar disease resistant groundnut genotypes (Arachis hypogaea L.). Electronic J. Plant Breed 1(4): 1021-1023.

Nigam, S.N., Dwivedi, S.L. and Gibbons, R.W. (1991): Groundnut breeding: constraints, achievements and future possibilities. Plant Breed. Abstr. 61: 1127-1136.

Thaware, B.L. (2009): Stability analysis for pod yield in Spanish bunch groundnut. Agric. Sci. Digest. 29(3): 221-223.

Upadhaya, H.D., Mukri, G., Nadaf, L. and Singh, S. (2012): Variability and stability analysis for nutritional traits in the mini core collection of peanut. Crop Sci. 52: 1-11.

Zhang, X., Han, S., Tang, F., Xu, J., Liu, H. and Yan, M. (2011): Genetic analysis of yield in peanut (Arachis hypogaea L.) using mixed model of major gene plus polygene. Afr.J. Biotechnol. 10: 7126-7130. 